\title{
Stabilizing effects on a Cd polluted coastal wetland soil using calcium polysulphide
}

\author{
Chen Tu ${ }^{\mathrm{a}}$, Feng Guan ${ }^{\mathrm{a}, \mathrm{b}}$, Yuhuan Sun ${ }^{\mathrm{b}}$, Pengpeng Guo ${ }^{\mathrm{a}}$, Ying Liu ${ }^{\mathrm{a}}$, Lianzhen Li ${ }^{\mathrm{a}}$, Kirk G. Scheckel ${ }^{\mathrm{d}}$, \\ Yongming Luo ${ }^{\mathrm{a}, \mathrm{c}, *}$ \\ ${ }^{a}$ Key Laboratory of Coastal Environmental Processes and Ecological Remediation, Yantai Institute of Coastal Zone Research, Chinese Academy of Sciences, Yantai 264003, \\ China \\ ${ }^{\mathbf{b}}$ College of Environment and Safety Engineering, Qingdao University of Science and Technology, Qingdao 266042, China \\ ${ }^{\mathrm{c}}$ Key Laboratory of Soil Environment and Pollution Remediation, Institute of Soil Science, Chinese Academy of Sciences, Nanjing 210008, China \\ d National Risk Management Research Laboratory, United States Environmental Protection Agency, Cincinnati 45224, USA
}

\section{A R T I C L E I N F O}

\section{Keywords:}

Cadmium

Calcium polysulfide

Bioavailability

Stabilization

Soil enzyme

Microbial diversity

\begin{abstract}
A B S T R A C T
In this study, different dosages of calcium polysulphide $\left(\mathrm{CaS}_{\mathrm{x}}\right)$ were used as an amendment to investigate effects on the immobilizing of $\mathrm{Cd}$ in a wetland soil by pot experiment. In addition to chemical analysis (pH and bioavailable Cd concentration), changes in soil enzyme activities, microbial carbon utilization capacity, metabolic and community diversity were examined to assess dynamic impacts on soil environmental quality and toxicity of Cd resulting from ameliorant dosing. Soil $\mathrm{pH}$ increased immediately upon $\mathrm{CaS}_{\mathrm{x}}$ amendment compared to the unamended control (CK), and then declined slowly to a level lower than CK. Diethylenetriamine pentaacetic acid (DTPA) extractable Cd concentration was determined to characterize the bioavailability of Cd in the soil. The $\mathrm{CaS}_{\mathrm{x}}$ dose-dependent effect observed that with increasing $\mathrm{CaS}_{\mathrm{x}}$ dosage, the immobilizing efficiency decreased. Soil urease and catalase activity assays and Biolog EcoPlate assay indicated that early stage addition of $\mathrm{CaS}_{\mathrm{x}}$ significantly inhibited soil microbial activities. However, mid and late stage time periods showed the inhibition effects were alleviated, and the microbial activities could be recovered in $1 \%$ and $2 \% \mathrm{CaS}_{\mathrm{x}}$ treatments. Moreover, with increasing incubation time, microbial community diversity and richness were significantly recovered in $1 \%$ and $2 \% \mathrm{CaS}_{\mathrm{x}}$ treatments compared to the CK. No considerable changes were observed in the $5 \%$ $\mathrm{CaS}_{\mathrm{x}}$ treatment. Conclusively, the $1 \% \mathrm{CaS}_{\mathrm{x}}$ amendment was an efficient and safe dosage for the stabilization of Cd contaminated wetland soil. This study contributes to the development of in situ remediation ameliorants and technologies for heavy metal polluted wetland soils.
\end{abstract}

\section{Introduction}

Coastal wetland is a transitional zone between the terrestrial and the marine ecosystem. It is strongly affected by global climate change and intensive anthropogenic activity. It provides essential ecosystem services to people and the environment, including providing production and living materials (such as food, raw materials and water resources), protecting biodiversity, degrading pollution and purifying the environment, regulating runoff floods and regional climate control, and serves as tourist and sightseeing destinations (Costa-Böddeker et al., 2017). In recent years, with the rapid development of industrialization, agricultural intensification and urbanization in the coastal zones, a large quantity of industrial wastes, agricultural fertilizers and pesticides, mining wastewaters, and municipal sewage have been emitted to the coastal wetland soils (Xu et al., 2017; Abad-Valle et al., 2016). Contaminants, such as heavy metals, could transfer from these potential waste streams into the coastal wetland soils causing pollution, and resulting human health and ecological risks to the coastal wetland soil ecosystem (Reddy et al., 2009; Bao et al., 2017). According to some investigations reviewed by Pan and Wang (2012), the average Cd concentration in estuarine and coastal environments in China varies from 0 to $9.7 \mathrm{mg} \mathrm{kg}^{-1}$. However, in some particular sites adjacent to mining and smelling districts in the coastal zone of China, Cd concentrations can be as high as $200-400 \mathrm{mg} \mathrm{kg}^{-1}$ (Fan et al., 2006; Zhong et al., 2017). Therefore, it is of great urgency to develop green and sustainable remediation technologies for cost-effective remediation of

\footnotetext{
* Corresponding author at: Key Laboratory of Coastal Environmental Processes and Ecological Remediation, Yantai Institute of Coastal Zone Research, Chinese Academy of Sciences, Yantai 264003, China.
}

E-mail address: ymluo@yic.ac.cn (Y. Luo). 
heavy metal polluted coastal wetland soils.

Unlike most organic contaminants, heavy metals in the soil cannot be totally degraded, but can be controlled and remediated through the following two in-situ strategies. One is to extract heavy metals from the polluted soil with technologies such as chemical/biological leaching and phytoextraction. The other is to decrease the mobility and bioavailability of heavy metals in the soil by adding natural or chemical/ biological synthesized amendments, also known as solidification/stabilization (Lee et al., 2009; Koptsik, 2014). Due to its economic efficiency and environmental compatibility, stabilization has been widely and successfully applied in the remediation of the heavy metal-polluted soils in farmland, industrial sites, mining areas, as well as coastal wetlands. Common stabilization agents used in the heavy metal polluted soils include phosphates (such as apatite, hydroxyapatite, bone meal, etc.), organic substances (such as humic acid, chitosan, straw, organic fertilizer, biochar, etc.) and other minerals (such as zeolite, lime, red mud, bentonite, sepiolite, etc.) (Lee et al., 2009; Janoš et al., 2010; Koptsik, 2014; Maletić et al., 2015; Abad-Valle et al., 2016; Guemiza et al., 2017). Their stabilization mechanisms vary with respect to different types of stabilization agents, soil physicochemical properties, as well as soil microbial activities.

Calcium polysulphide $\left(\mathrm{CaS}_{\mathrm{x}}\right)$, also called lime sulfur, is a common soil bactericide and insecticide which has been widely applied in prevention and eradication of plant diseases and insect pests in agricultural production approved by the United States Department of Agriculture (USDA). Due to its strong reducibility and solidification of heavy metals, $\mathrm{CaS}_{\mathrm{x}}$ has been considered as an ideal stabilization agent, and has been applied in the control and remediation of chromium (Cr) contaminated soil and waste water (Yahikozawa et al., 1978; Chrysochoou et al., 2010; Chrysochoou and Ting, 2011; Kameswari et al., 2015). $\mathrm{CaS}_{\mathrm{x}}$ rapidly transformed hexavalent chromium (Cr(VI)) from a highly mobile and toxic species to the immobile and lower toxicological $\mathrm{Cr}(\mathrm{III})$ form, which caused the geochemical fixation of $\mathrm{Cr}$ (Fruchter, 2002). Chrysochoou et al. (2010) added $\mathrm{CaS}_{\mathrm{x}}$ to $\mathrm{Cr}(\mathrm{VI})$-contaminated soils and found the solubility of transformed $\mathrm{Cr}(\mathrm{III})$ was continually decreased over one year of incubation, indicating high efficiency and long-term stabilization of Cr. Maletić et al. (2015) compared the stabilization effects of four ameliorants, including bone meal, activated carbon, bentonite and $\mathrm{CaS}_{\mathrm{x}}$ to the stabilization of $\mathrm{Pb}, \mathrm{Cu}$ and Ni-contaminated soils. They found $\mathrm{CaS}_{\mathrm{x}}$ had better stabilization effects on the heavy metals than other ameliorants, and the stabilization effects increased with increasing dosages of $\mathrm{CaS}_{\mathrm{x}}$. However, to our knowledge, researches regarding on the remediation of Cd-contaminated soil by $\mathrm{CaS}_{\mathrm{x}}$ are very limited. Furthermore, the environmental impacts of $\mathrm{CaS}_{\mathrm{x}}$ application to the coastal wetland soil ecosystem remain unclear.

The aim of the present study was therefore to investigate the stabilization effects of $\mathrm{CaS}_{\mathrm{x}}$ on the remediation of Cd-contaminated wetland soil, and to clarify the dosage-dependent effects of $\mathrm{CaS}_{\mathrm{x}}$ application on soil enzyme activities and soil microbial metabolic and community diversity. The results of this study will be helpful to the development of an efficient, safe and long-acting stabilization soil amendment for the in-situ remediation of Cd-contaminated wetland soil.

\section{Materials and methods}

\subsection{Physicochemical properties of the tested soil}

The tested soil was collected from the surface layer of the coastal wetland in Shandong Province, China. The basic physicochemical properties were as follow: $\mathrm{pH} 7.85$, soil organic matter $8.04 \mathrm{~g} \mathrm{~kg}^{-1}, \mathrm{EC}$ $0.13 \mathrm{~ms} \mathrm{~cm}^{-1}$, total $\mathrm{N} 0.56 \mathrm{~g} \mathrm{~kg}^{-1}$, total $\mathrm{P} 1.09 \mathrm{~g} \mathrm{~kg}^{-1}$, total $\mathrm{K}$ $15.36 \mathrm{~g} \mathrm{~kg}^{-1}$, CEC $5.40 \mathrm{cmol} \mathrm{kg}^{-1}$, Na $13.88 \mathrm{~g} \mathrm{~kg}^{-1}$, Ca $14.81 \mathrm{~g} \mathrm{~kg}^{-1}$, $\mathrm{Cd} 0.22 \mathrm{mg} \mathrm{kg}^{-1}$, sandy loam. It belongs to Fluvisols according to the FAO soil classification system.

\subsection{Preparation of the soil stabilization amendment $\mathrm{CaS}_{x}$}

The tested soil stabilization amendment $\mathrm{CaS}_{\mathrm{x}}$ was prepared according to the method modified from Levchenko et al. (2015). Briefly, $\mathrm{CaO}, \mathrm{S}$ and distilled water were mixed $(1: 2: 15)$ and heated at $100{ }^{\circ} \mathrm{C}$ for $2 \mathrm{~h}$ to produce the $\mathrm{CaS}_{\mathrm{x}}$ by the following reaction:

$\mathrm{CaO}+\mathrm{S}+\mathrm{H}_{2} \mathrm{O} \rightarrow \mathrm{CaS}_{\mathrm{x}}+\mathrm{CaS}_{2} \mathrm{O}_{3}+\mathrm{CaCO}_{3}$

The reaction yields $\mathrm{CaS}_{4}$ and $\mathrm{CaS}_{5}(64-67 \%)$ and by-products of $\mathrm{CaS}_{2} \mathrm{O}_{3}(23-28 \%)$ and $\mathrm{CaCO}_{3}(0.3-1.1 \%)$, with $5-11 \%$ unreacted sulfur remaining. The main active ingredient of $\mathrm{CaS}_{\mathrm{x}}$ are $\mathrm{CaS}_{\mathrm{x}}(\mathrm{x}=5-8)$ as well as other components such as $\mathrm{HS}^{-}, \mathrm{CaSO}_{4}, \mathrm{CaO}, \mathrm{S}$ and $\mathrm{Ca}(\mathrm{OH})_{2}$. The mixture was then filtered after it was cooled to room temperature. The filtered $\mathrm{CaS}_{\mathrm{x}}$ was a dark orange solution, while the pale-yellow precipitate was composed of $\mathrm{CaS}_{2} \mathrm{O}_{3}, \mathrm{CaCO}_{3}$, and unreacted sulfur. Since $\mathrm{CaS}_{\mathrm{x}}$ can be easily oxidized when exposed to air, the filtered $\mathrm{CaS}_{\mathrm{x}}$ was sealed by liquid paraffin and stored in the bottle before using.

\subsection{Soil stabilization remediation experiment design}

The tested soil was disaggregated and sieved to a final size of $<2$ $\mathrm{mm}$ after air dried. $5 \mathrm{~kg}$ of sieved soil was artificially spiked with $500 \mathrm{~mL}$ of $\mathrm{Cd}\left(\mathrm{NO}_{3}\right)_{2}$ stock solution (Cd concentration $2.1 \mathrm{~g} \mathrm{~L}^{-1}$ ), and aged for 2 weeks to attain equilibrium. The final concentration of total $\mathrm{Cd}$ in the soil was $95 \mathrm{mg} \mathrm{kg}^{-1}$. Soil moisture content was adjusted to $30 \%$ of the water holding capacity (WHC) before the pot experiment.

Soil stabilization remediation was conducted by pot experiment. Four treatments were designed with different $\mathrm{CaS}_{\mathrm{x}}$ amendment dosage: (i) Cd spiked soil without $\mathrm{CaS}_{\mathrm{x}}$ amendment (CK), (ii) Cd spiked soil with $1 \%(v: m) \mathrm{CaS}_{\mathrm{x}}$ amendment (C1), (iii) Cd spiked soil with $2 \%(v: m) \mathrm{CaS}_{\mathrm{x}}$ amendment (C2) and (iv) Cd spiked soil with 5\% (v:m) $\mathrm{CaS}_{\mathrm{x}}$ amendment (C5). Each pot was filled with $300 \mathrm{~g}$ (dry weight) soil with the WHC maintained at $30 \%$. All the treatments were conducted in the green house at room temperature, with 3 replicates. Soil samples were collected from all the treatments at $0 \mathrm{~d}$ ( $30 \mathrm{~min}), 3$ days, 15 days, 30 days, 40 days and 55 days, respectively, for further analysis.

\subsection{Soil $p H$ and total Cd analysis}

Soil $\mathrm{pH}$ was measured by $\mathrm{pH}$ meter (F2, Mettler Toledo, Switzerland) at a 1:2.5 (w:v) ratio of soil and deionized water. The total $\mathrm{Cd}$ content in the soil was analyzed using a $\mathrm{HNO}_{3}-\mathrm{HF}-\mathrm{HClO}_{4}$ digestion followed by flame atomic absorption spectrometry (AA7000, Shimadzu, Japan).

\subsection{Soil bioavailable Cd analysis}

Diethylenetriamine pentaacetic acid (DTPA) is a one-step extracting agent that has been widely used to predict the bioavailability of heavy metals in soil (Udovic and Lestan, 2012; Luce et al., 2017). In this research, DTPA extractable Cd was adopted to characterize the bioavailability of Cd in the soil according to Kopittke et al. (2017). $10 \mathrm{~mL}$ of DTPA extracting agent was added into a $50-\mathrm{mL}$ tube containing $5 \mathrm{~g}$ of air-dried soil passed through a $1 \mathrm{~mm}$ mesh. The mixture was oscillated at $180 \mathrm{r} \mathrm{min}^{-1}, 25^{\circ} \mathrm{C}$ for $2 \mathrm{~h}$, then filtered and diluted before the analysis of bioavailable $\mathrm{Cd}$ detected by atomic absorption spectrometry.

\subsection{Soil enzymatic activities assay}

Soil urease activity was determined using the sodium hypochlorite-sodium phenate colorimetry assay with urea as the substrate, and was expressed as $\mathrm{mg} \mathrm{NH}_{4}{ }^{+}-\mathrm{N} \mathrm{g}^{-1} 24 \mathrm{~h}^{-1}$ (Bhaduri et al., 2016). Soil catalase activity was determined using the permanganimetric assay with hydrogen peroxide as the substrate, and was expressed as $\mathrm{mL}$ (0.1 $\left.\mathrm{mol} \mathrm{L}^{-1} \mathrm{KMnO}_{4}\right) \mathrm{h}^{-1} \mathrm{~g}^{-1}$ (Jorge-Mardomingo et al., 2013). Blank matrix control was set for each treatment, while blank sample and 
matrix control were set during the whole experiment.

\subsection{Soil microbial carbon utilization characteristics}

Soil microbial carbon source utilization characteristics were analyzed using the Biolog EcoPlate assay (Jiang et al., 2017). The Biolog EcoPlate (Biolog Inc., Hayward, USA) contains 31 of the most useful carbon sources for soil community analysis, which belong to 6 categories including carbohydrates, carboxylic acids, polymers, amino acids, phenolic acids and amines. Soil suspensions $(150 \mu \mathrm{L})$ were inoculated directly into Biolog EcoPlates and the microplates were incubated and analyzed at defined time intervals. Formation of purple color occurs when the microbes can utilize the carbon source and begin to respire. The community-level physiological profile is assessed by the rate of average well color development (AWCD) measured at $\mathrm{OD}_{590}$ on a microplate reader. The AWCD value is calculated according to formula (2) (Braun et al., 2010).

AWCD value $=\sum\left(C_{i}-R\right) / 31$

Here, $C_{i}$ is the $\mathrm{OD}_{590}$ value of the $i$ th non-control well, $R$ is the $\mathrm{OD}_{590}$ value of the control well, and 31 is the number of carbon sources in the Biolog EcoPlate.

\subsection{Soil microbial community diversity}

Soil microbial community diversity indexes, i.e. Shannon index $(H)$ and Simpson index $(D)$ are calculated using the following formulas according to Liu et al. (2017):

$H=-\sum p_{i}\left(\ln p_{i}\right)$

$\frac{1}{D}=\sum \frac{\left(n_{i}\left(n_{i}-1\right)\right)}{(\mathrm{N}(\mathrm{N}-1))}$

Here, $p_{i}$ is the ratio between the relative $\mathrm{OD}_{590}$ value $\left(C_{i}-R\right)$ of the $i$ th well and the sum of the entire plate, $n_{i}$ is the relative $\mathrm{OD}_{590}$ value $\left(C_{i}-R\right)$ of the $i$ th well, $\mathrm{N}$ is the sum of $\mathrm{OD}_{590}$ value. Soil microbial community Richness index $(R)$ refers to the total number of carbon sources used by soil microbes. It is expressed as the number of wells whose $\mathrm{OD}_{590}$ value $\left(C_{i}-R\right)>0.15$ in each plate (Mahabadi et al., 2007).

\subsection{Statistical analysis}

Mean values and standard deviation (SD) of the data were calculated by Excel 2016. The statistical analysis was conducted using SPSS Statistics 21.0 software. The significant difference analysis was evaluated by the Duncan's test of difference analysis variance (ANOVA). Differences were considered significant at $p<0.05$.

\section{Results}

\subsection{Dynamics of soil $p H$ and DTPA extractable Cd concentration}

Soil $\mathrm{pH}$ variation dynamics in $\mathrm{Cd}$ polluted wetland soil amended by different dosages of $\mathrm{CaS}_{\mathrm{x}}$ is presented in Fig. 1. Within the entire remediation duration, soil $\mathrm{pH}$ in the control treatment $(\mathrm{CK})$ without $\mathrm{CaS}_{\mathrm{x}}$ application maintained in an alkalescent range $(\mathrm{pH} 7.86 \pm 0.1)$, while soil $\mathrm{pH}$ in all the $\mathrm{CaS}_{\mathrm{x}}$ amendment groups showed a significant increase relative to the control immediately after addition of $\mathrm{CaS}_{\mathrm{x}}$ to the soil (30 min, 0 day). The soil pH in $1 \%, 2 \%$ and $5 \% \mathrm{CaS}_{\mathrm{x}}$ treatments were respectively $8.28,8.61$ and 9.16 . The $\mathrm{pH}$ enhancement was directly correlated with the increasing of $\mathrm{CaS}_{\mathrm{x}}$ dosage. However, as reaction time progressed, soil $\mathrm{pH}$ in all $\mathrm{CaS}_{\mathrm{x}}$ treatments showed a rapid decrease. At the end of the experiment (Day 55), soil pH of all the treatments with $\mathrm{CaS}_{\mathrm{x}}$ amendment were significantly lower than $\mathrm{CK}$, and the extent of $\mathrm{pH}$

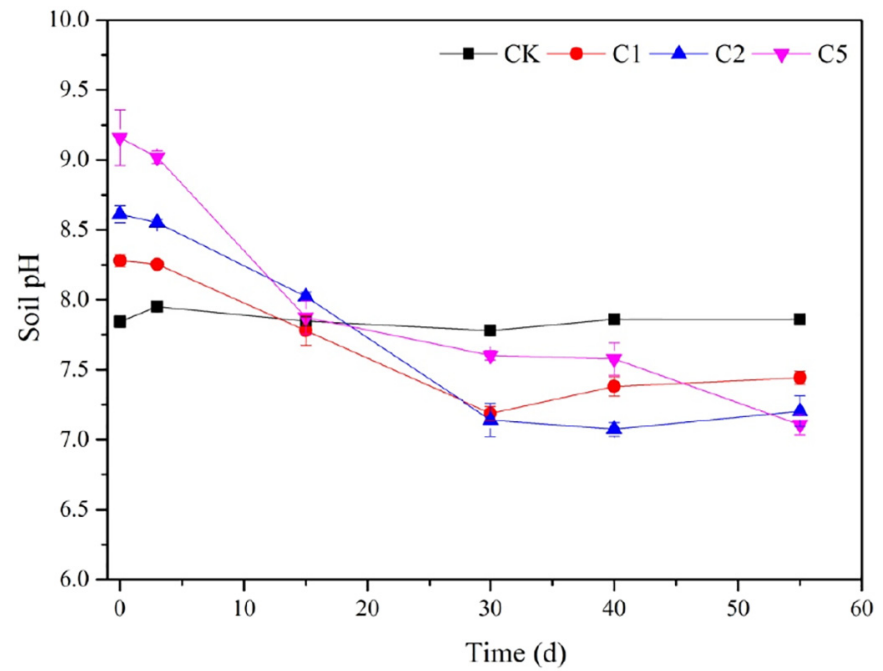

Fig. 1. Dynamic changes of soil $\mathrm{pH}$ under different doses of $\mathrm{CaS}_{\mathrm{x}}$ amendment.

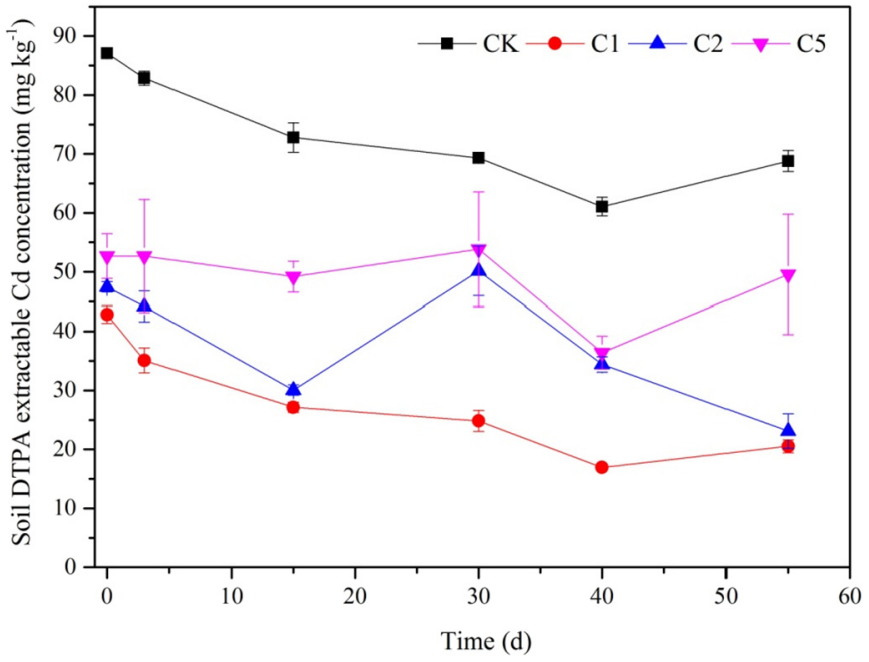

Fig. 2. Dynamic changes of soil DTPA extractable Cd concentration under different doses of $\mathrm{CaS}_{\mathrm{x}}$ amendment.

decrease was positively correlated with dosage level of $\mathrm{CaS}_{\mathrm{x}}$ $(p<0.05)$.

Dynamics of soil DTPA extractable Cd concentration in different treatments is shown in Fig. 2. DTPA extractable Cd concentrations in $1 \%, 2 \%$ and $5 \% \mathrm{CaS}_{\mathrm{x}}$ treatments were $42.84,47.47$ and $52.69 \mathrm{mg} \mathrm{kg}^{-1}$, respectively, which were significantly decreased compared with $\mathrm{CK}$ (87.10 $\mathrm{mg} \mathrm{kg}^{-1}$ ) immediately after the addition of $\mathrm{CaS}_{\mathrm{x}}$ (30 min, 0 day). Upon aging, DTPA extractable Cd concentration in C1 group kept decreasing within the entire experiment period and was markedly lower than that in C2 and C5. At the end of the experiment (Day 55), DTPA extractable Cd concentrations in CK, C1, C2 and C5 were 61.06, 20.53, 23.10 and $49.59 \mathrm{mg} \mathrm{kg}^{-1}$, respectively. For all the treatments with $\mathrm{CaS}_{\mathrm{x}}$ amendment, DTPA extractable Cd was significantly lower than that of the CK. The stabilization effect of $\mathrm{CaS}_{\mathrm{x}}$ on soil Cd was not positively correlated with the dosage of $\mathrm{CaS}_{\mathrm{x}}$. On the contrary, the most efficient treatment for $\mathrm{Cd}$ immobilization was $\mathrm{C} 1$ with the lowest $\mathrm{CaS}_{\mathrm{x}}$ amendment.

\subsection{Dynamics of soil urease and catalase activities}

Urease and catalase are two types of typical soil enzymes that are widely used for the evaluation of soil environmental quality and microbial activities. Dynamics of soil urease and catalase activities in the 

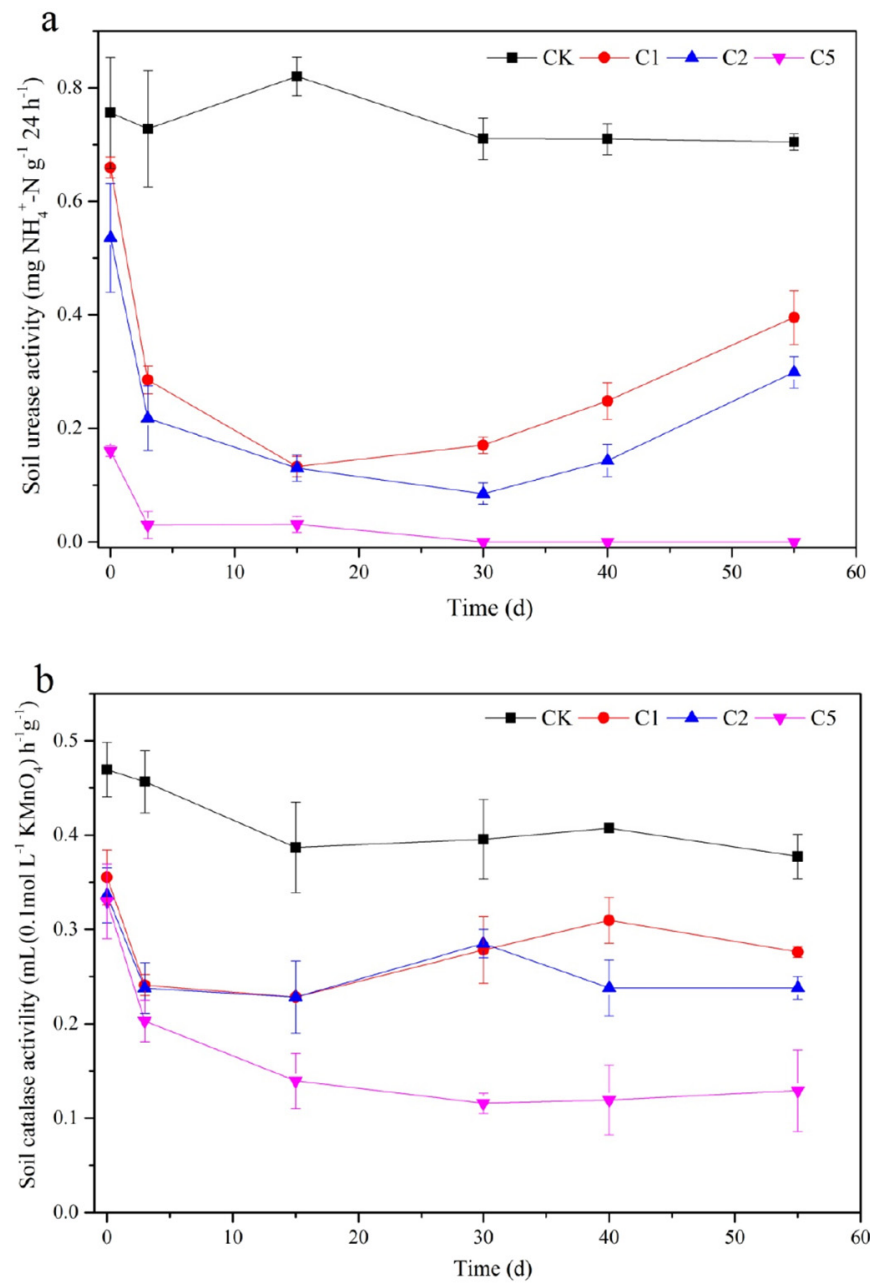

Fig. 3. Dynamic changes of soil enzyme activities under different doses of $\mathrm{CaS}_{\mathrm{x}}$ amendment (a: urease activity, b: catalase activity).

Cd polluted soil amended by $\mathrm{CaS}_{\mathrm{x}}$ are presented in Fig. 3. Soil urease activity decreased significantly $(p<0.05)$ in all treatments immediately after $\mathrm{CaS}_{\mathrm{x}}$ was added to the soil. At Day 0 (30 min), soil urease activities in $1 \%, 2 \%$ and $5 \% \mathrm{CaS}_{\mathrm{x}}$ treatments were reduced by $12.74 \%, 18.79 \%$ and $70.03 \%$ compared to the CK. As reaction time increased, urease activity in $\mathrm{C} 1$ kept declining to $0.13 \mathrm{mg} \mathrm{NH}_{4}^{+} \mathrm{N} \mathrm{g}^{-1} 24 \mathrm{~h}^{-1}$ during the first 15 days, then it slowly recovered, increasing to $0.40 \mathrm{mg} \mathrm{NH}_{4}^{+} \mathrm{N} \mathrm{g}^{-1} 24 \mathrm{~h}^{-1}$ at the end of experiment (Day 55). Urease activity in $\mathrm{C} 2$ was similar to $\mathrm{C} 1$, except the recovery inflexion starts later (Day 30 ) than $\mathrm{C} 1$, and the soil urease activity in $\mathrm{C} 2\left(0.30 \mathrm{mg} \mathrm{NH}_{4}{ }^{+} \mathrm{Ng}^{-1} 24 \mathrm{~h}^{-1}\right)$ was significantly lower than $\mathrm{C} 1$ at Day 55. However, urease activity in C5 was totally different from that of $\mathrm{C} 1$ and $\mathrm{C} 2$. Through Day 3, soil urease activity in C5 decreased rapidly to $0.03 \mathrm{mg} \mathrm{NH}_{4}^{+} \mathrm{N} \mathrm{g}^{-1} 24 \mathrm{~h}^{-1}$, and maintained at a very low level around the detection limit for the duration of the study. There was no significant change for soil urease activity in the CK group during the whole experiment.

The general dynamics of soil catalase activities were similar to the urease activities (Fig. 3b). Compared to CK, soil catalase activities decreased significantly $(p<0.05)$ in all treatments immediately after $\mathrm{CaS}_{\mathrm{x}}$ was added to the soil. For $1 \%$ and $2 \% \mathrm{CaS}_{\mathrm{x}}$ treatments, soil catalase activities kept declining in the first 15 days and started to rise afterward. At the end of the experiment (Day 55), soil catalase activities in $\mathrm{C} 1$ and $\mathrm{C} 2$ had recovered to 0.27 and $0.24 \mathrm{~mL}\left(0.1 \mathrm{~mol} \mathrm{~L}^{-1}\right.$ $\left.\mathrm{KMnO}_{4}\right) \mathrm{h}^{-1} \mathrm{~g}^{-1}$, respectively, which were still significantly lower than that in CK $(p<0.05)$. Dynamics of soil catalase activity in C5 was different from $\mathrm{C} 1$ and $\mathrm{C} 2$. It kept declining in the first 30 days to the
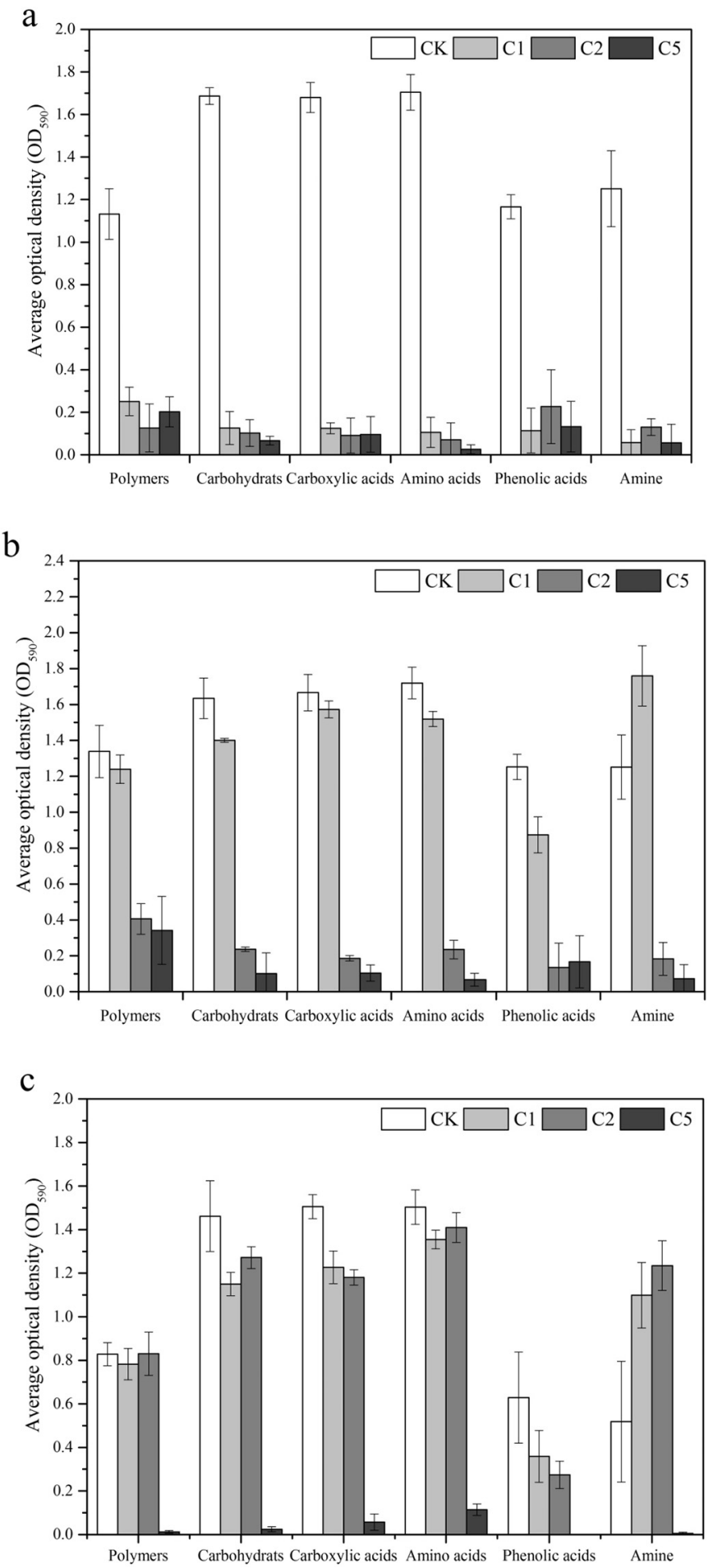

Fig. 4. Dynamic changes of soil microbial carbon utilization capacity under different doses of $\mathrm{CaS}_{\mathrm{x}}$ amendment (a: 3 days, b: 30 days, c: 55 days).

minimum of $0.12 \mathrm{~mL}\left(0.1 \mathrm{~mol} \mathrm{~L}^{-1} \mathrm{KMnO}_{4}\right) \mathrm{h}^{-1} \mathrm{~g}^{-1}$, and remained stable at this level until the end of the experiment without any recovery.

\subsection{Dynamics of soil microbial carbon utilizing capability}

Thirty-one of the commonly used carbon sources in the Biolog EcoPlates were classified into 6 categories including carbohydrates, carboxylic acids, polymers, amino acids, phenolic acids and amines. Kinetic effects of different $\mathrm{CaS}_{\mathrm{x}}$ dosages on soil microbial carbon utilization capability are shown in Fig. 4. On Day 3, microbial utilization of 


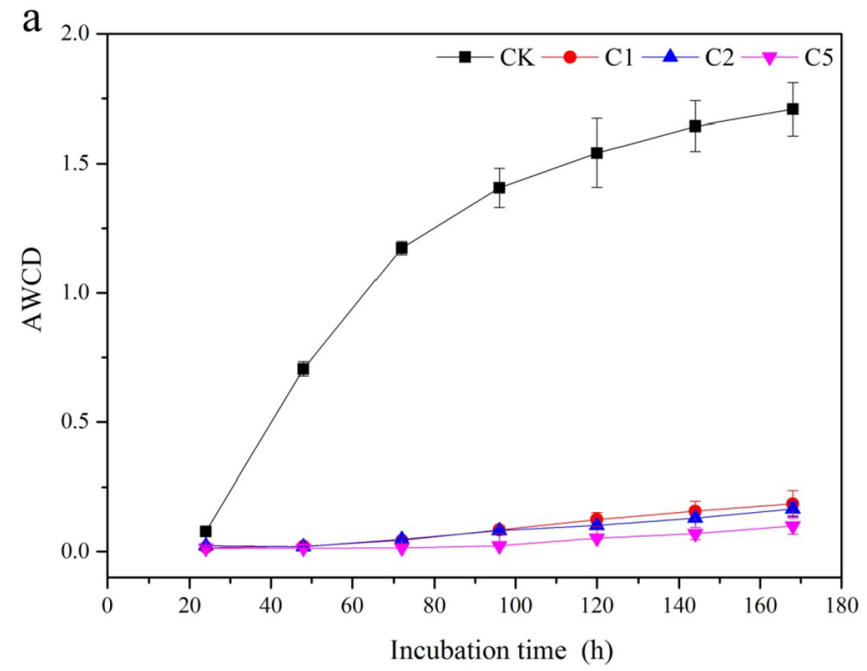

b
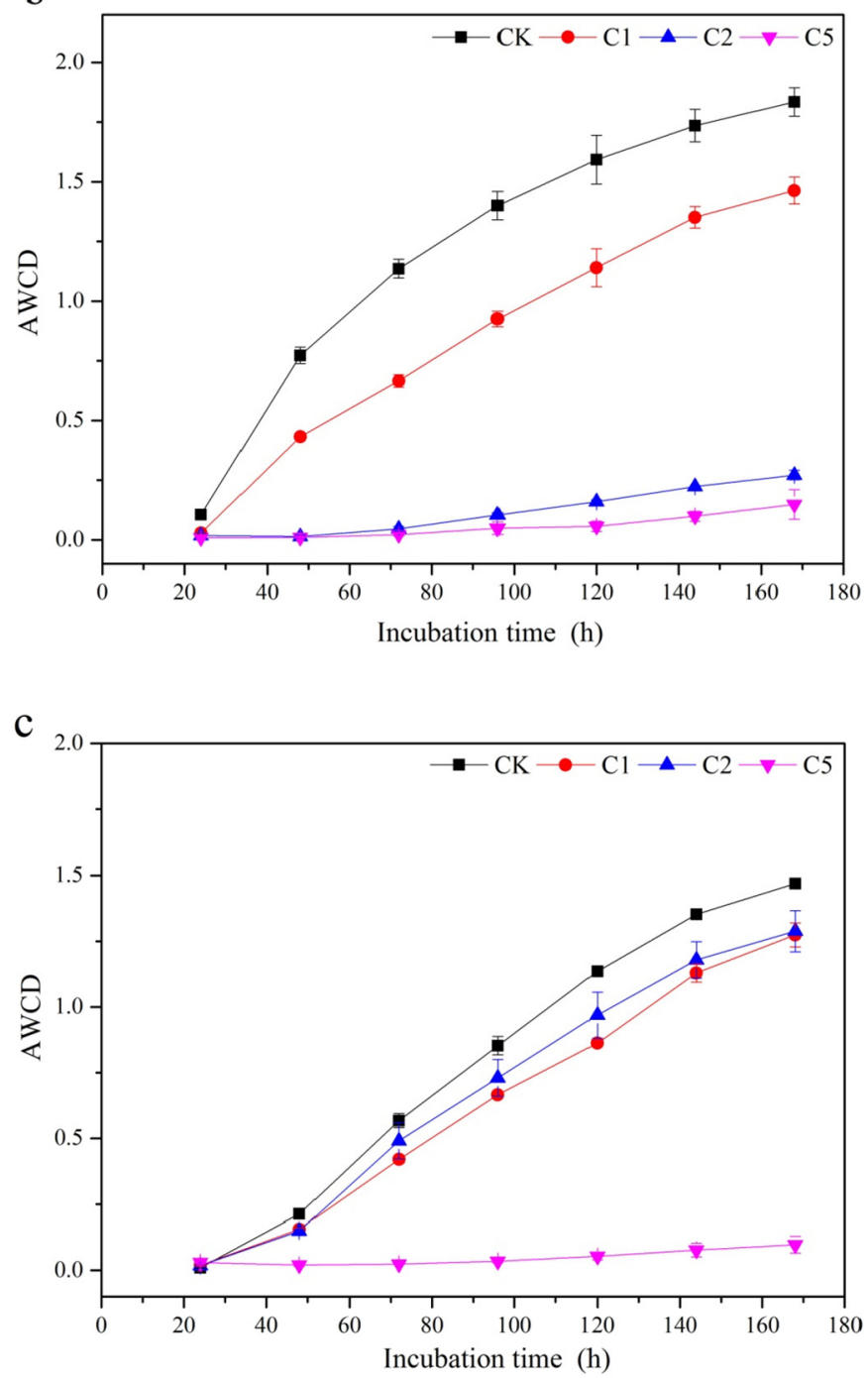

Fig. 5. Dynamic changes of AWCD value of soil microbial community under different doses of $\mathrm{CaS}_{\mathrm{x}}$ amendment (a: 3 days, b: 30 days, c: 55 days).

all the six carbon substrate categories was significantly inhibited in all the $\mathrm{CaS}_{\mathrm{x}}$ treatments relative to CK (Fig. 4a). With increased incubation time, microbial utilization of all six carbon substrate categories in the
$1 \% \mathrm{CaS}_{\mathrm{x}}$ treatment started to show a significant increase on Day 30, while $2 \%$ and $5 \% \mathrm{CaS}_{\mathrm{x}}$ treatments had no obvious recovery (Fig. $4 \mathrm{~b}$ ). On Day 55, all the categories of carbon substrates except phenolic acid significantly recovery in both $1 \%$ and $2 \% \mathrm{CaS}_{\mathrm{x}}$ treatments, but not in the $5 \% \mathrm{CaS}_{\mathrm{x}}$ treatment.

\subsection{Dynamics of soil microbial community diversity}

AWCD of Biolog EcoPlates was used as an indicator of soil microbial metabolic activity. Variation of AWCD with incubation time is presented in Fig. 5. Three days after $\mathrm{CaS}_{\mathrm{x}}$ application, AWCD in all the $\mathrm{CaS}_{\mathrm{x}}$ amended groups decreased significantly (Fig. 5a). On Day 30, AWCD in C1 showed an obvious enhancement relative to C2 and C5, but still significantly lower than CK (Fig. 5b). On Day 55 of $\mathrm{CaS}_{\mathrm{x}}$ amendment, AWCD in both $1 \%$ and $2 \% \mathrm{CaS}_{\mathrm{x}}$ treatments increased significantly to near the level of CK, while AWCD in C5 had no obvious change during the incubation (Fig. 5c).

The effects of different $\mathrm{CaS}_{\mathrm{x}}$ dosages on soil microbial community diversity, as reflected by Shannon, Simpson and Richness indices, are listed in Table 1. As shown in Table 1, the Shannon, Simpson and Richness indices decreased significantly 3 days after $\mathrm{CaS}_{\mathrm{x}}$ amendment, and the differences of these indices among various $\mathrm{CaS}_{\mathrm{x}}$ dosages were not considerable. On Day 30, the Shannon, Simpson and Richness indices in $1 \%$ and $2 \% \mathrm{CaS}_{\mathrm{x}}$ treatments increased significantly compared to Day 3, but still lower than CK. On Day 55, the Shannon, Simpson and Richness indices in $1 \%$ and $2 \% \mathrm{CaS}_{\mathrm{x}}$ treatments had recovered to the level of CK $(p<0.05)$, while none of these indices in $5 \% \mathrm{CaS}_{\mathrm{x}}$ treatment showed any enhancement during the incubation.

\section{Discussion}

The migration and transformation of heavy metals in polluted soil and sediment can be hindered by stabilization techniques based on amendments of suitable immobilizing agents. Adsorption of heavy metals on mineral surfaces, formation of stable complexes with organic ligands, surface precipitation and ion-exchange are identified as the main mechanisms responsible for the reduction of the metal mobility, leachability and bioavailability. The key to the control and remediation of heavy metal polluted wetland soil is the screening and characterizing of proper stabilization agents, including clay minerals, lime, red mud, biochar and $\mathrm{CaS}_{\mathrm{x}}$, etc. (Bradl, 2004; Garau et al., 2007; Luce et al., 2017; Qiao et al., 2017).

\subsection{Effects of $\mathrm{CaS}_{x}$ on soil $\mathrm{pH}$ and metal bioavailability}

In this study, within the first 15 days after different doses (1\%, $2 \%$ and $5 \%)$ of $\mathrm{CaS}_{\mathrm{x}}$ addition, soil $\mathrm{pH}$ was significantly enhanced compared to the $\mathrm{CK}$, and the level of $\mathrm{pH}$ increase showed a positive correlation with the dosage of $\mathrm{CaS}_{\mathrm{x}}$ (Fig. 1). This is mainly due to the original physico-chemical features of $\mathrm{CaS}_{\mathrm{x}}$ synthesized in this research. $\mathrm{CaS}_{\mathrm{x}}$ is a dark orange solution, with an alkaline $\mathrm{pH}(\mathrm{pH}=11.0)$. It may contain various chain species including hepta-, octa-, and nano-sulphide with a pH ranging from 6.0 to 11.0 (Gun et al., 2004; Kamyshny et al., 2007). $\mathrm{CaS}_{\mathrm{x}}$ solution can enhance soil $\mathrm{pH}$ rapidly and significantly as soon as it interacts with the soil solid or liquid components. On the other hand, $\mathrm{CaS}_{\mathrm{x}}$ solution is unstable in soil and water environments containing $\mathrm{O}_{2}$ and $\mathrm{CO}_{2}$. With increased incubation time, $\mathrm{CaS}_{\mathrm{x}}$ decomposes rapidly in the soil with the participation of $\mathrm{O}_{2}$ and $\mathrm{CO}_{2}$, producing $\mathrm{H}_{2} \mathrm{~S}, \mathrm{CaCO}_{3}$, $\mathrm{CaSO}_{4}$, and solid sulfur particles. The reaction equations are listed as follows:

$\mathrm{CaS}_{\mathrm{x}}+3 / 2 \mathrm{O}_{2} \rightarrow \mathrm{CaS}_{2} \mathrm{O}_{3}+(x-2) \mathrm{S}$

$\mathrm{CaS}_{\mathrm{x}}+\mathrm{CO}_{2}+\mathrm{H}_{2} \mathrm{O} \rightarrow \mathrm{CaCO}_{3}+\mathrm{H}_{2} \mathrm{~S}+(x-1) \mathrm{S}$

In soil or wastewater containing heavy metals, the immobilization reactions can be explained as: 
Table 1

Dynamic changes of soil microbial community diversity under different doses of $\mathrm{CaS}_{\mathrm{x}}$ amendments.

\begin{tabular}{|c|c|c|c|c|}
\hline Sampling time(d) & Treatment & Shannon index $(H)$ & Simpson index $(D)$ & Richness index $(R)$ \\
\hline \multirow[t]{4}{*}{3} & CK & $3.30 \pm 0.04 \mathrm{a}$ & $26.30 \pm 0.85 a$ & $28.00 \pm 1.00 \mathrm{a}$ \\
\hline & $\mathrm{C} 1$ & $2.53 \pm 0.17 b$ & $10.75 \pm 2.06 b$ & $9.67 \pm 3.21 b$ \\
\hline & $\mathrm{C} 2$ & $1.97 \pm 0.60 \mathrm{~b}$ & $6.25 \pm 4.46 \mathrm{~b}$ & $6.00 \pm 2.65 b c$ \\
\hline & $\mathrm{C} 5$ & $2.30 \pm 0.13 b$ & $7.59 \pm 1.34 \mathrm{~b}$ & $4.67 \pm 2.31 \mathrm{c}$ \\
\hline \multirow[t]{4}{*}{30} & CK & $3.32 \pm 0.35 \mathrm{a}$ & $26.52 \pm 0.84 \mathrm{a}$ & $29.00 \pm 1.73 \mathrm{a}$ \\
\hline & $\mathrm{C} 1$ & $3.19 \pm 0.01 \mathrm{ab}$ & $22.29 \pm 0.38 \mathrm{~b}$ & $25.33 \pm 0.58 \mathrm{a}$ \\
\hline & $\mathrm{C} 2$ & $2.81 \pm 0.15 \mathrm{~b}$ & $14.40 \pm 2.57 \mathrm{c}$ & $13.67 \pm 2.89 b$ \\
\hline & $\mathrm{C} 5$ & $2.21 \pm 0.40 \mathrm{c}$ & $7.39 \pm 2.85 \mathrm{~d}$ & $7.00 \pm 3.61 c$ \\
\hline \multirow[t]{4}{*}{55} & $\mathrm{CK}$ & $3.22 \pm 0.04 \mathrm{a}$ & $23.67 \pm 1.21 \mathrm{a}$ & $25.00 \pm 1.00 \mathrm{a}$ \\
\hline & $\mathrm{C} 1$ & $3.22 \pm 0.05 \mathrm{a}$ & $23.49 \pm 1.19 \mathrm{a}$ & $26.67 \pm 1.53 \mathrm{a}$ \\
\hline & $\mathrm{C} 2$ & $3.16 \pm 0.03 \mathrm{a}$ & $22.04 \pm 0.79 \mathrm{a}$ & $24.33 \pm 0.58 \mathrm{a}$ \\
\hline & $\mathrm{C} 5$ & $2.11 \pm 0.16 \mathrm{~b}$ & $6.20 \pm 0.75 b$ & $5.33 \pm 0.58 \mathrm{~b}$ \\
\hline
\end{tabular}

Different letters in the table indicate significant differences in the data in each column (p $<0.05)$.

$\mathrm{M}^{2+}+\mathrm{CaS}_{2} \mathrm{O}_{3}+\mathrm{CaS}_{2} \mathrm{O}_{3} \rightarrow \mathrm{MS} \downarrow+\mathrm{CaSO}_{4}+2 \mathrm{H}^{+}$

$\mathrm{M}^{2+}+\mathrm{H}_{2} \mathrm{~S} \rightarrow \mathrm{MS} \downarrow+2 \mathrm{H}^{+}$

Here, M represents the heavy metal cations, MS represents the precipitated metal sulphides (Dahlawi and Siddiqui, 2017). As the reaction goes on, heavy metals in the soil are stabilized in the form of MS precipitation, while $\mathrm{H}^{+}$also accumulated in the soil, causing decreasing soil $\mathrm{pH}$ at equilibrium. Our results are in line with Chrysochoou et al. (2010), who have reported that within the first 60 days after $\mathrm{CaS}_{\mathrm{x}}$ applied to $\mathrm{Cr}$ (VI) polluted soil, soil pH was initially enhanced from 6.0 to 11.0 and gradually declined to 8.0 to 8.5 within 1 year.

In this research, after $\mathrm{CaS}_{\mathrm{x}}$ amendment to the soil, DTPA extractable Cd concentration in the soil decreased significantly compared to CK. Moreover, the decreasing level of DTPA extractable Cd concentration in the soil was inversely correlated with the $\mathrm{CaS}_{\mathrm{x}}$ dosage (Fig. 2). According to the literatures, appropriate dosage of $\mathrm{CaS}_{\mathrm{x}}$ amendment could chemically react with heavy metals in the soil, and produces stable metal sulfide or precipitation of hydroxide, which can reduce the mobility of heavy metal (Aratani et al., 1979; Chrysochoou et al., 2010; Maletić et al., 2015; Dahlawi and Siddiqui, 2017). However, excessive dosage of $\mathrm{CaS}_{\mathrm{x}}$ amendment may initiate the formation of a soluble metal ion complex $\left[\mathrm{MS}_{\mathrm{x}}\right]^{\mathrm{n}-}$, thus causing the dissolution and re-mobilization of metal cations from the precipitated compounds (Li, 2014). In this research, $1 \% \mathrm{CaS}_{\mathrm{x}}$ amendment was deemed as the appropriate dosage, which brings a continuous stabilization effect on Cd in the soil. Higher concentration ( $2 \%$ and $5 \%$ ) of $\mathrm{CaS}_{\mathrm{x}}$ amendment resulted in significantly weaker Cd stabilization effects than $1 \% \mathrm{CaS}_{\mathrm{x}}$ treatment. The excessive $\mathrm{CaS}_{\mathrm{x}}$ may react with $\mathrm{Cd}$ and produce soluble complexes of $\left[\mathrm{CdS}_{2}\right]^{2-}$, which enhances the mobilization and migration of $\mathrm{Cd}$ in the wetland soil. However, further analysis for Cd speciation in the soil is needed, with the utilization of synchrotron-based $\mu \mathrm{XRD}, \mu \mathrm{XRF}$ and $\mu X A N E S$ techniques. Likewise, investigation of lower $(<1 \%) \mathrm{CaS}_{\mathrm{x}}$ amendment levels or multiple lower $\mathrm{CaS}_{\mathrm{x}}$ amendment levels on $\mathrm{Cd}$ immobilization would help clarify the appropriate soil dosage.

\subsection{Effects of $\mathrm{CaS}_{x}$ on soil microbial enzymatic activities}

Although a considerable body of work exists concerning the effects of $\mathrm{CaS}_{\mathrm{x}}$ on the stabilization of heavy metals in soil and wastewater, there are few reports regarding the impacts of $\mathrm{CaS}_{\mathrm{x}}$ on soil environmental quality and ecosystem functions. Soil enzymatic activity is an important indicator for accessing the status of soil environmental quality. For example, urease is an essential soil enzyme that catalyzes urea hydrolysis into ammonia and carbonic acid. It plays an important role in the soil nitrogen cycling driven by soil microorganisms (Garau et al., 2007; Bhaduri et al., 2016). Catalase is an anti-oxidative enzyme, which directly converts $\mathrm{H}_{2} \mathrm{O}_{2}$ to $\mathrm{H}_{2} \mathrm{O}$ and $\mathrm{O}_{2}$ (Willekens et al., 1997). Changes of catalase activity in the soil indicates the occurrence of oxidative stress induced by various environmental stresses, including soil contamination by heavy metals and other hazardous pollutants (Shrestha et al., 2013; Wyrwicka and Urbaniak, 2016). In this research, within the early stage (0-15 day) after $\mathrm{CaS}_{\mathrm{x}}$ addition (Fig. 3a), soil urease and catalase activities in all $\mathrm{CaS}_{\mathrm{x}}$ treatments were significantly declined compared to $\mathrm{CK}$, indicating considerable acute toxicity of $\mathrm{CaS}_{\mathrm{x}}$ to soil microbial activities in $\mathrm{N}$ cycling and oxidative stress. Eqs. (6) and (7) demonstrate that after $\mathrm{CaS}_{\mathrm{x}}$ was amended to the soil, $\mathrm{H}_{2} \mathrm{~S}$ and $\mathrm{S}^{0}$ were produced concurrently with the stabilizing of heavy metals in the soil. However, $\mathrm{H}_{2} \mathrm{~S}$ and $\mathrm{S}^{0}$ may also inhibit soil microbial activities and soil ecosystem functions to some extent (Aratani et al., 1979; Dahlawi and Siddiqui, 2017). Dorman et al. (2002) reported that $\mathrm{H}_{2} \mathrm{~S}$ could directly inhibit the activity of cytochrome oxidase which is a key enzyme in mitochondrial respiration, while $S^{0}$ could oxidize cytochrome $b$ and produce $\mathrm{H}_{2} \mathrm{~S}$, causing further cell oxidative damage. Moreover, the inhibited enzyme activity shows a significant dosage-dependent effect. In this research, at the early stage after $\mathrm{CaS}_{\mathrm{x}}$ addition (0-15 day), the decreasing level of soil urease and catalase was positively correlated with the increasing of $\mathrm{CaS}_{\mathrm{x}}$ dosage. As the remediation time increased, urease and catalase activities in $1 \%$ and $2 \% \mathrm{CaS}_{\mathrm{x}}$ treatments showed significant increase, indicating the inhibition to soil microbial activity had been alleviated. However, urease and catalase activities in $5 \% \mathrm{CaS}_{\mathrm{x}}$ treatment showed no recovery from the initial exposure, indicating an irreversible damage to microbial activities (Fig. 3b \& 3c).

\subsection{Effects of $\mathrm{CaS}_{x}$ on soil microbial metabolic and community diversity}

Carbon source utilization capability has been shown to be a satisfactory indicator of describing microbial metabolic profile and soil environmental quality, because it reflects the potential of microbes to respond promptly to environmental changes (Garland and Mills, 1991; Yao et al., 2003; Guo et al., 2015). Biolog EcoPlate is a quick, effective, and inexpensive method used to detect the dynamic variation of microbial metabolic and community diversity in soil, especially in contaminated soil (Sprocati et al., 2014; Guo et al., 2015). Although many studies have found that $\mathrm{CaS}_{\mathrm{x}}$ had high-efficiency on the stabilization of heavy metals $(\mathrm{Cr}, \mathrm{Pb}, \mathrm{Cu}$ and $\mathrm{Ni})$ in soil, few researches are available on the environmental effects of $\mathrm{CaS}_{\mathrm{x}}$ amendments to coastal wetland soils. According to a USEPA toxicity report for direct human exposure, $\mathrm{CaS}_{\mathrm{x}}$ has a high $\mathrm{pH}$ around 11.5, which may cause irreversible damage to the eyes and light corrosion to the skin upon contact (USEPA, 2005). In this study, we report for the first time the soil microbial carbon utilization capability (Fig. 4), microbial metabolic diversity indicated by AWCD (Fig. 5), and microbial community diversity indicated by Shannon, Simpson and Richness indices (Table 1) were significantly decreased in the $\mathrm{CaS}_{\mathrm{x}}$ treatments compared to $\mathrm{CK}$ at the initial stage of the incubation. The above decreasing levels are closely related to the $\mathrm{CaS}_{\mathrm{x}}$ dosage. Bailey et al. (2012) also reported that $\mathrm{CaS}_{\mathrm{x}}$ could significantly inhibit the growth of specific bacterial strain Shewanella oneidensis, and a dose 
dependent effect was also observed. However, in the mid and later stage of incubation, the adverse effects of $\mathrm{CaS}_{\mathrm{x}}$ amendment are alleviated, as evident by the recovery of soil microbial metabolic and community diversity from Day 30. This result is consistent with Maletić et al. (2015), who reported that the addition of $\mathrm{CaS}_{\mathrm{x}}$ could not only effectively stabilize metal contaminated soils, but also reduce the microbial toxicity of heavy metal in the pore water of soil. Considering cost feasibility, the price of commercially available $\mathrm{CaS}_{\mathrm{x}}(500 \$ / \mathrm{t})$ is slightly more expensive than biochar $(300 \$ / \mathrm{t})$; however, the recommended effective dose for biochar is $5 \%$, which is 5 -fold greater than the effective $\mathrm{CaS}_{\mathrm{x}}$ recommended amendment rate of $1 \%$. Taking cost and efficiency into account, $\mathrm{CaS}_{\mathrm{x}}$ can be considered as an economically and environmentally friendly amendment for the in-situ stabilization of $\mathrm{Cd}$ contaminated wetland soil.

\section{Conclusions}

The stabilizing effects and environmental impacts of $\mathrm{CaS}_{\mathrm{x}}$ amendments in Cd polluted wetland soil were investigated individually in this study. $\mathrm{CaS}_{\mathrm{x}}$ could significantly decrease the bioavailability and microbial toxicity of $\mathrm{Cd}$ in the soil, thus reduced the environmental risk of the $\mathrm{Cd}$ in the wetland soil ecosystem. The levels of bioavailable $\mathrm{Cd}$, soil urease and catalase, microbial carbon utilization ability, and microbial metabolic and community diversity in the wetland soil were closely related to the $\mathrm{CaS}_{\mathrm{x}}$ dose. $\mathrm{CaS}_{\mathrm{x}}$ amendment of $1 \%$ was an efficient and safe dosage for the stabilization of $\mathrm{Cd}$ in the wetland soil. To our knowledge, this is the first report that assessing the Cd stabilizing efficiency and environmental impacts in wetland soil using $\mathrm{CaS}_{\mathrm{x}}$. Results from this study should provide useful scientific evidence for the development of in-situ remediation ameliorants and technologies for heavy metal polluted wetland soils.

\section{Acknowledgements}

The current research was funded by the National Key R\&D Program of China (2016YFE0106400), the National High Technology Research and Development Program (2012AA06A204-4, 2013AA06A211-4), and the National Natural Science Foundation of China (41571310).

\section{References}

Abad-Valle, P., Álvarez-Ayuso, E., Murciego, A., Pellitero, E., 2016. Assessment of the use of sepiolite amendment to restore heavy metal polluted mine soil. Geoderma 280, $57-66$.

Aratani, T., Yasuhara, S., Matoba, H., Yano, T., 1979. Continuous removal of heavy metals by the lime Sulfurated solution (calcium polysulfide) process. Bull. Chem. Soc. Jpn. 52 (1), 218-222.

Bailey, K.L., Tilton, F., Jansik, D.P., Ergas, S.J., Marshall, M.J., Miracle, A.L., Wellman, D.M., 2012. Growth inhibition and stimulation of Shewanella oneidensis MR-1 by surfactants and calcium polysulfide. Ecotoxicol. Environ. Saf. 80 (2), 195-202.

Bao, K., Shen, J., Sapkota, A., 2017. High-resolution enrichment of trace metals in a west coastal wetland of the southern Yellow Sea over the last 150 years. J. Geochem. Explor. 176, 136-145.

Bhaduri, D., Saha, A., Desai, D., Meena, H.N., 2016. Restoration of carbon and microbial activity in salt-induced soil by application of peanut shell biochar during short-term incubation study. Chemosphere 148 (4), 86-98.

Bradl, H.B., 2004. Adsorption of heavy metal ions on soils and soils constituents. J. Colloid Interface Sci. 277 (1), 1-18.

Braun, B., Böckelmann, U., Grohmann, E., Szewzyk, U., 2010. Bacterial soil communities affected by water-repellency. Geoderma 158 (3-4), 343-351.

Chrysochoou, M., Ting, A., 2011. A kinetic study of $\mathrm{Cr}(\mathrm{VI})$ reduction by calcium polysulfide. Sci. Total Environ. 409 (19), 4072-4077.

Chrysochoou, M., Ferreira, D.R., Johnston, C.P., 2010. Calcium polysulfide treatment of Cr(VI)-contaminated soil. J. Hazard. Mater. 179 (1-3), 650-657.

Costa-Böddeker, S., Hoelzmann, P., Thuyên, L.X., Huy, H.D., Nguyen, H.A., Richter, O., Schwalb, A., 2017. Ecological risk assessment of a coastal zone in southern Vietnam: spatial distribution and content of heavy metals in water and surface sediments of the Thi Vai estuary and can Gio mangrove Forest. Mar. Pollut. Bull. 114 (2), 1141-1151.

Dahlawi, S.M., Siddiqui, S., 2017. Calcium polysulphide, its applications and emerging risk of environmental pollution - a review article. Environ. Sci. Pollut. Res. 24 (1), 92.

Dorman, D.C., Moulin, F.J., Mcmanus, B.E., Mahle, K.C., James, R.A., Struve, M.F., 2002. Cytochrome oxidase inhibition induced by acute hydrogen sulfide inhalation: correlation with tissue sulfide concentrations in the rat brain, liver, lung, and nasal epithelium. Toxicol. Sci. 65 (1), 18-25.

Fan, W.H., Zhang, B., Chen, J.S., Zhang, R., Deng, B.S., 2006. Pollution and potential biological toxicity assessment using heavy metals from surface sediments of Jinzhou Bay. Acta Sci. Circumst. 26 (6), 1000-1005 (In Chinese).

Fruchter, J., 2002. In situ treatment of chromium-contaminated groundwater. Environ. Sci. Technol. 36 (23), 464A-472A.

Garau, G., Castaldi, P., Santona, L., Deiana, P., Melis, P., 2007. Influence of red mud, zeolite and lime on heavy metal immobilization, culturable heterotrophic microbial populations and enzyme activities in a contaminated soil. Geoderma 142 (1), 47-57.

Garland, J., Mills, A., 1991. Classification and characterization of heterotrophic microbial communities on the basis of patterns of community-level sole-carbo-source utilization. Appl. Environ. Microbiol. 57, 2351-2359.

Guemiza, K., Coudert, L., Metahni, S., Mercier, G., Besner, S., Blais, J., 2017. Treatment technologies used for the removal of As, $\mathrm{Cr}, \mathrm{Cu}, \mathrm{PCP}$ and/or PCDD/F from contaminated soil: a review. J. Hazard. Mater. 333, 194-214.

Gun, J., Modestov, A., Kamyshny, A., Ryzkov, D., Gitis, V., Goifman, A., 2004. Electrospray ionization mass spectrometric analysis of aqueous polysulfide solutions. Microchim. Acta 146 (3-4), 229-237.

Guo, P.P., Zhu, L.S., Wang, J.H., Wang, J., Liu, T., 2015. Effects of alkyl-imidazolium ionic liquid $[\mathrm{Omim}] \mathrm{Cl}$ on the functional diversity of soil microbial communities. Environ. Sci. Pollut. Res. 22 (12), 9059-9066.

Janoš, P., Vávrová, J., Herzogová, L., Pilařová, V., 2010. Effects of inorganic and organic amendments on the mobility (leachability) of heavy metals in contaminated soil: a sequential extraction study. Geoderma 159 (3-4), 335-341.

Jiang, L.L., Han, G.M., Lan, Y., Liu, S.N., Gao, J.P., Yang, X., Meng, J., Chen, W.F., 2017. Corn cob biochar increases soil culturable bacterial abundance without enhancing their capacities in utilizing carbon sources in Biolog Eco-plates. J. Integr. Agric. 16 (3), 713-724.

Jorge-Mardomingo, I., Soler-Rovira, P., Casermeiro, M.Á., Cruz, M.T., Polo, A., 2013. Seasonal changes in microbial activity in a semiarid soil after application of a high dose of different organic amendments. Geoderma 206 (9), 40-48.

Kameswari, K.S.B., Pedaballe, V., Narasimman, L.M., Kalyanaraman, C., 2015 Remediation of chromite ore processing residue using solidification and stabilization process. Environ. Prog. Sustain. Energy 34 (3), 674-680.

Kamyshny, A., Gun, J., Rikzov, D., Voitsekovski, T., Lev, O., 2007. Equilibrium distribution of polysulfide ions in aqueous solutions at different temperatures by rapid single phase derivatization. [J]. Environ. Sci. Technol. 41 (7), 2395-2400.

Kopittke, P.M., Dalal, R.C., Menzies, N.W., 2017. Changes in exchangeable cations and micronutrients in soils and grains of long-term, low input cropping systems of subtropical Australia. Geoderma 285, 293-300.

Koptsik, G.N., 2014. Modern approaches to remediation of heavy metal polluted soils: a review. Eurasian Soil Sci. 47 (7), 707-722.

Lee, S.H., Lee, J.S., Choi, Y.J., Kim, J.G., 2009. In situ stabilization of cadmium-, lead-, and zinc-contaminated soil using various amendments. Chemosphere 77 (8), 1069-1075.

Levchenko, L.M., Galitskii, A.A., Kosenko, V.V., Sagidullin, A.K., 2015. Development of semi-industrial synthesis of calcium polysulfide solution and determination of the content of sulfide ions in solution. Russ. J. Appl. Chem. 88 (9), 1403-1408.

Li, S., 2014. Innocuous treatment of wastewater containing mercury by polysulfide complex reactions. Focus Polyvinyl Chloride 42 (5), 39-43 (in Chinese).

Liu, M., Liu, J., Jiang, C., Wu, M., Song, R.S., Gui, R.Y., Jia, J.X., Li, Z.P., 2017. Improved nutrient status affects soil microbial biomass, respiration, and functional diversity in a lei bamboo plantation under intensive management. J. Soils Sediments 17 (4), 917-926.

Luce, M.S., Ziadi, N., Gagnon, B., Karam, A., 2017. Visible near infrared reflectance spectroscopy prediction of soil heavy metal concentrations in paper mill biosolid- and liming by-product-amended agricultural soils. Geoderma 288, 23-36.

Mahabadi, A.A., Hajabbasi, M.A., Khademi, H., Kazemian, H., 2007. Soil cadmium stabilization using an Iranian natural zeolite. Geoderma 137 (3-4), 388-393.

Maletić, S.P., Watson, M.A., Dehlawi, S., Diplock, E.E., Mardlin, D., Paton, G.I., 2015. Deployment of microbial biosensors to assess the performance of ameliorants in metal-contaminated soils. Water Air Soil Pollut. 226 (4), 85.

Pan, K., Wang, W.X., 2012. Trace metal contamination in estuarine and coastal environments in China. Sci. Total Environ. 421-422, 3-16.

Qiao, J., Sun, H., Luo, X., Zhang, W., Mathews, S., Yin, X.Q., 2017. EDTA-assisted leaching of $\mathrm{Pb}$ and $\mathrm{Cd}$ from contaminated soil. Chemosphere 167, 422-428.

Reddy, K.R., Delaune, R.D., Reddy, K.R., Delaune, R.D., 2009. Biogeochemistry of wetlands: science and applications. Biogeochemistry of Wetlands Science \& Applications 73 (2), 1779.

Shrestha, B., Martinezb, V.A., Cox, S.B., Green, M.J., Li, S., Canas-Carrell, J.E., 2013. An evaluation of the impact of multiwalled carbon nanotubes on soil microbial community structure and functioning. J. Hazard. Mater. 261, 188-197.

Sprocati, A.R., Alisi, C., Tasso, F., Fiore, A., Marconi, P., Langella, F., Haferburg, G., Nicoara, A., Neagoe, A., Kothe, E., 2014. Bioprospecting at former mining sites across Europe: microbial and functional diversity in soils. Environ. Sci. Pollut. Res. 21, 6824. https://doi.org/10.1007/s11356-013-1907-3.

Udovic, M., Lestan, D., 2012. EDTA and HCl leaching of calcareous and acidic soils polluted with potentially toxic metals: remediation efficiency and soil impact. Chemosphere 88 (6), 718-724.

USEPA, 2005. Office of prevention, pesticides and other toxic substances. In: Reregistration Eligibility Decision for Inorganic Polysulfides. ListD-case no. 4054. September 30 .

Willekens, H., Chamnongpol, S., Davey, M., Schraudner, M., Langebartels, C. Vanmontagu, M., Inze, D., Vancamp, W., 1997. Catalase is a sink for $\mathrm{H}_{2} \mathrm{O}_{2}$ and is indispensable for stress defence in C-3 plants. EMBO J. 16, 4806-4816.

Wyrwicka, A., Urbaniak, M., 2016. The different physiological and antioxidative 
responses of zucchini and cucumber to sewage sludge application. PLoS One 11 (6), e0157782. https://doi.org/10.1371/journal.pone.0157782.

Xu, L., Wang, T.Y., Wang, J.H., Lu, A.X., 2017. Occurrence, speciation and transportation of heavy metals in 9 coastal rivers from watershed of Laizhou Bay, China. Chemosphere 173, 61-68.

Yahikozawa, K., Aratani, T., Ito, R., Sudo, T., Yano, T., 1978. Kinetic studies on the lime sulfurated solution (calcium polysulfide) process for removal of heavy metals from wastewater. Bull. Chem. Soc. Jpn. 51 (2), 613-617.

Yao, H.Y., Xu, J.M., Huang, C.Y., 2003. Substrate utilization pattern, biomass and activity of microbial communities in a sequence of heavy metal-polluted paddy soils. Geoderma 115, 139-148.

Zhong, X.M., Xia, D.S., Song, B., Chen, T.B., 2017. Review on soil cadmium study and risk assessment in Guangxi. J. Nat. Resour. 32 (7), 1256-1270 (In Chinese). 